\title{
PREVENTIVE CONSERVATION PLAN FOR THE CHAPEL OF SUSUDEL, ECUADOR
}

\author{
G. Barsallo ${ }^{1,}$, M. C. Achig ${ }^{1}$ \\ ${ }^{1}$ CPM project - University of Cuenca, Av. 12 de Abril y Loja, Cuenca - Ecuador - (gabriela.barsallo, cecilia.achig)@ucuenca.edu.ec
}

Commission II - WG II/8

KEYWORDS: Susudel, Conservation, Heritage, Architecture

\begin{abstract}
Ecuador is blessed by the presence of age-old buildings and places that deserve to be preserved. One of these places is Susudel, whose historical center was declared Cultural Heritage of Ecuador in 2013. One of the most emblematic buildings in the province of Azuay is located here, the chapel of Susudel. This chapel, which belongs to a large estate, is an example of colonial architecture in which traditional construction techniques and materials have been used, such as adobe, bricks, wood and roof tiles. This ancestral knowledge typical of vernacular heritage architecture deserves to be preserved for the enjoyment of future generations. This investigation shows several constructive elements that give a special technological value to the chapel. The interior of the chapel contains a significant sample of murals, which constitute a religious symbol of the colonial era. The aim of this investigation is to establish conservation strategies through the identification of stakeholders, roles, maintenance actions and maintenance tools that result in a preventive conservation and monitoring plan for the chapel. The methodology used is based on the preventive conservation phases as proposed by ICOMOS 2003: anamnesis, diagnosis, therapy and control, which is complemented by recommendations that include the active participation of the community and institutions responsible for the conservation of built heritage.
\end{abstract}

\section{INTRODUCTION}

Earthen architecture corresponds to one of the most used construction systems worldwide. Until 2011, around $50 \%$ of the total earthen architecture was located in southern parts of America, Africa, Asia, and Europe. According to CRAterre (Gandreau, et al., 2012), around 150 world heritage sites of the total listed by UNESCO correspond to earthen architecture and the majority of them (26\%) are located in Latin America. In Ecuador, earthen architecture has been around since the pre-Inca era, through the colonial and the republican era, up until now, especially in the Andes region. The province in this region with the second largest number of adobe buildings is Azuay (Garcia, et al, 2016). In this province, vernacular architecture has an important presence not only in rural areas but also in urban ones, such as the Historic City Center of Cuenca, which was included as a World Heritage Site in 1999. The Chapel of Susudel is located at approximately $80 \mathrm{~km}$ from Cuenca in the province of Azuay. This article shows several constructive elements typical to the rural vernacular architecture of the colonial era in Ecuador, which have been conserved in the Chapel.

The conservation of heritage assures that elements of value survive through time for present and future generations. Various concepts about preventive conservation are based on reflections, such as those of Adolphe Napoleón Didron, who said: 'for ancient monuments, it is better to consolidate than to repair, better to repair than to restore, and better to restore than to reconstruct' (Astudillo, 2011). ICOM-CC, which is one of 30 International Committees that are part of the International Council of Museums, addresses conservation as 'all measures and actions aimed at safeguarding tangible cultural heritage

Corresponding author

The vlirCPM project (Vlaamse Interuniversitaire Raad - City Preservation Management), in coordination with a consortium of Flemish Universities, lasted from the year 2007 until 2018. Its objective was to develop scientific foundations and provide education while ensuring its accessibility to present and future generations. Conservation embraces preventive conservation, remedial conservation and restoration. All measures and actions should respect the significance and the physical properties of the cultural heritage item' (ICOM-CC, 2008). It is thus observed that from various theoretical perspectives, conservation promotes preventive actions with different scopes, which all foment measures that are aimed at preserving the meaning and the physical properties of the heritage item.

Preventive conservation has as its motto "Prevention is better than cure" from the Dutch philosopher Erasmus. Instead of thinking of costly restoration investments, it should be understood that it is better to prevent through minor efforts, reserving a yearly budget for the maintenance of the heritage item (Barsallo, 2019). Furthermore, the change of mentality of the owners as well as of the technicians in charge of safeguarding the heritage item is fundamental when it comes to applying preventive actions that allow the control of its deterioration.

Several monuments and sites in Ecuador are at risk for different reasons, such as abandonment, poorly executed interventions and lack of maintenance. This investigation focuses on one of the most emblematic monuments in the province of Azuay in the south of the Ecuadorian Andes, the Chapel of Susudel. Its vernacular architecture shows the use of traditional construction techniques and materials, such as adobe, bricks, wood and roof tiles. Several tools developed by the vlirCPM ${ }^{1}$, Ciudad Patrimonio Mundial (CPM) were used during the investigation. The result of the investigation is a preventive conservation plan that includes maintenance interventions for the conservation and protection of the chapel of Susudel.

in order to improve the management of heritage sites in southern Ecuador, through the creation of management tools and the diffusion of knowledge. Currently the project is known as the CPM Project (City Preservation Management). 


\section{METHODOLOGY}

To determine the phases of the Preventive Conservation Plan, the methodology for the study of damages in heritage structures used by ICOMOS (2003), anamnesis, diagnosis, therapy and control, was used (Achig et al., 2014).

Anamnesis. This term is often used in medicine and refers to the collection and the recovery of information given during an interview to the doctor by a patient (Astudillo, 2011). It is important to research the historical information related to the original state of the structures and their consecutive stages as well as the techniques and the skills used in its construction, reconstructions, modifications, additions, restorations and structural changes. All this information leads to the determination of the present condition of the building (ICOMOS, 2014).

Diagnosis. The act or process of identifying or determining the nature and the cause of the damage and decay through observation, investigation and historical analysis (ICOMOS, 2014). The identification of the causes that led to a damage allows to know the condition of the building, with the aim of determining the level of intervention required in the next phase (Achig, et al., 2016).

Therapy. "The choice of remedial measures (reinforcement, strengthening, replacement, etc.) in response to the diagnosis." (ICOMOS, 2014)

Control. In this phase, cyclical and regular monitoring actions are undertaken, such as the implementation of strategies for a preventive conservation plan (Achig, et al., 2016).

\subsection{Preventive conservation tools to determine the damages and values of the Chapel of Susudel}

In each of the phases previously described several tools were developed and applied to adequately monitor, define and undertake preventive conservation actions in the Chapel of Susudel.

The Nara Matrix: Is based on the recommendations of the Nara Document on Authenticity (1994), which emphasizes two key aspects of the determination of heritage values: authenticity and integrity (Cardoso, et al., 2018). The Nara Matrix was used as a methodological strategy and complemented by a historical study to identify the values of the chapel.

The damage registration system: It requires the organization of information following precise steps that are comparable to those used in preventive medicine and which correspond to the preventive conservation cycle. In order to achieve cost effectiveness and a minimal impact on architectural heritage, it is usually necessary for these steps to be repeated in an iterative process (ICOMOS, 2003). The four phases: anamnesis, diagnosis, therapy and control are the inputs for the elaboration of a preventive conservation plan. Interventions, such as in the chapel of Susudel, should be designed for easy management and they should be registered in a maintenance plan based on a monitoring system (Della Torre, 2013). "Recording, documentation and information system techniques are used at all stages of work (preventive conservation cycle). They are essential to understanding the values of the site, as well as its condition" (Santana, 2013).

The Damage Atlas: Is a guide to identify damages in heritage buildings. In this document one can find a classification and codification of damages, possible causes, materials and it complements the reference system (Achig-Balarezo, Barsallo, 2018).

\section{METHODOLOGICAL DEVELOPMENT FOR THE PREVENTIVE CONSERVATION OF THE CHAPEL OF SUSUDEL}

\subsection{Anamnesis}

3.1.1 Heritage and architectural values: The Chapel of Susudel is located in the province of Azuay, belonging to the canton of Oña and is located in its only rural parish, Susudel. (Figure 1) The chapel was completed in the year 1752 and forms part of the Susudel Estate. This was a large estate constituted by plots of lands belonging to natives. The estate maintained its integrity until the agrarian reform in the 1960's, through which, with the redistribution of land, peasants obtained title of the land by means of concessions granted by the state (Cardoso, 2015).

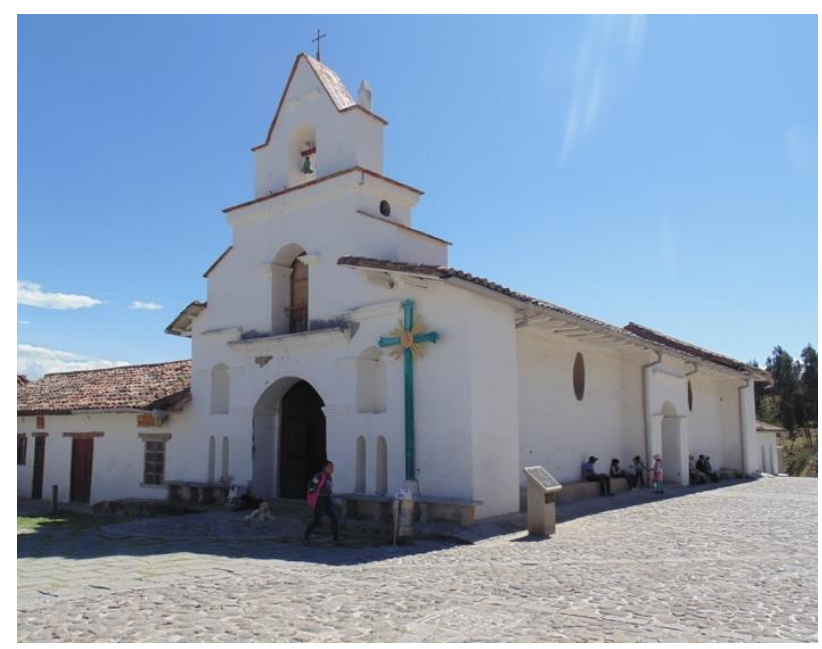

Figure 1. The chapel of Susudel Source: Barsallo, 2019.

Susudel is characterized as being a place in which the natural landscape combines grasslands, valleys and hills with the vernacular architecture of adobe. In addition, it has a large production of handcrafted bricks.

In the year 2013, its historical center was declared Cultural Heritage of Ecuador. The chapel of Susudel is one of the most emblematic monuments of sacred architecture of rural Ecuador and contains in its walls inscriptions that reveal important events of its history. The chapel was built as part of a large estate, attached to several buildings and located next to the central square, the so-called "escaramuza square". Currently, the curia is its owner (Barsallo, 2019).

3.1.2 Architectural configuration: The modest chapel is made up of a rectangular shape (central nave and altar complemented by the baptistery) (Figure 2). It has two entrances, one towards the central square and one towards the atrium of the chapel. Its walls are made of adobe and include niches. Furthermore, it contains oculi to enable the entrance of light. It has a valuable collection of murals. A hidden treasure is found behind its main wooden altar in the form of an altar that contains a set of murals, but which over time have lost its colors. "The murals of the chapel of Susudel show the peculiarities of a rural chapel, including the specific concern of showing harmony between the inhabitants of the world through religion" (Lloret, et al., 2008) and the connection with the city. The characteristics of some of the murals of the old Cathedral of the city of Cuenca are similar to those found in the chapel of Susudel and can be attributed to the same painter, Juan de Orellana (Paniagua, 1993). 
The front façade is made up of different elements, such as the bell tower, ledges, pilasters, niches and skirting boards. The influence of the city is present in this rural chapel through the owners of the estate who lived in the city of Cuenca and brought trends from one place to the other (Barsallo, 2019).

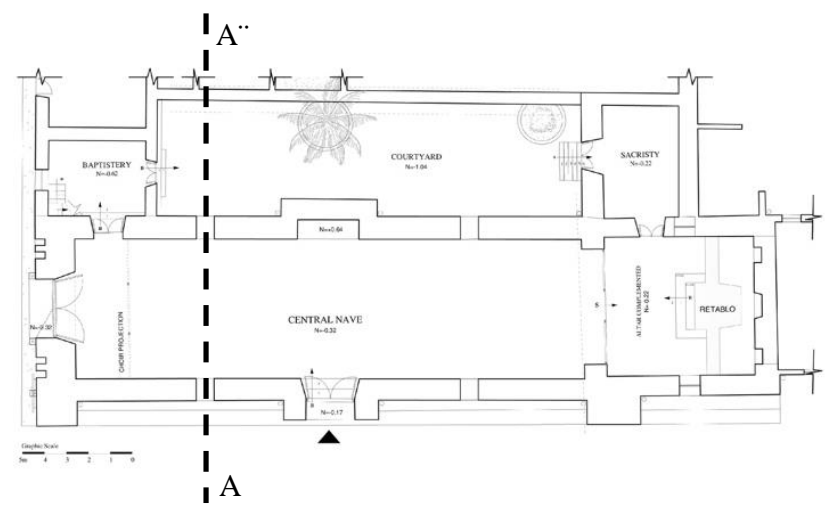

Figure 2. Architectural drawing of the chapel of Susudel. Source: Barsallo, 2019

3.1.3 Valuation: Heritage valuation begins when people, institutions and communities want to use their past and realize that it is worth keeping (Avrami, Mason, R, n.d.). The community gives meaning and value to tangible and intangible heritage, which is why the determination of the values of the chapel of Susudel is based on three analysis aspects: a) historical and contextual through the gathering of bibliographic information, b) valuation determined from different stakeholders: public, private, religious, professional, academic and community, c) construction of the Nara Matrix as an instrument to better understand the concept of authenticity (Van Balen, 2008). The chapel is an example of colonial architecture that is part of the heritage buildings of the Susudel estate. It shows the presence of traditional materials and construction techniques that indicate the knowledge of the use of these techniques and materials (adobe, bricks, wood and roof tiles) and the passing on of this knowledge from generation to generation. Additionally, the murals of the chapel are an artistic exhibition with symbolic meaning of the colonial era. The chapel has maintained its religious use throughout history. Currently the community shows a sense of appropriation, which is shown through the communal work (so-called minga) of together cleaning the chapel and together decorating the chapel in times of festivities. The chapel plays an important role in the social cohesion of the community, it offers spaces for meetings as well as religious events.

3.1.4 Main traditional materials and construction systems used in rural architecture in Azuay: The chapel of Susudel contains elements typical to rural vernacular architecture in Ecuador. The traditional materials and construction systems used to make these elements are:

Adobe walls: Bricks made of raw earth that form a wall based on elements molded from earth with the help of fibrous material such as straw and other fibers, joined with mud in its vertical and horizontal joints (Piedra, 2008). With the arrival of the Spaniards during the colonial era, the use of adobe was intensified as the main construction system of walls. This construction technique has from early times on been accompanied by the use of plaster as a coating for its protection. Its use was popular until the midnineteenth century, when economic, social and cultural changes caused a slow transformation in the architecture of the city (Caldas, Sigcha, 2017).

In the chapel of Susudel, all walls are made of adobe bricks. The thickness of the bearing walls is $1,10 \mathrm{~m}$ (Muñoz, 1990). The walls contain several elements of value, such as murals. Each side façade has 2 oculi $^{2}$. The front façade is made up of a bell tower, several ledges, pilasters and niches (Figure 1).

Wooden roof structure: The wooden roof structure of the chapel is made of tie beams that are supported by the adobe walls, rafters and a ridgepole. Several corbels are located in the lateral walls (Figure 3). These elements are decorated with barroque carvings. The complete roof structure is made of wood. On top of the wooden structure reed is placed and tied with strings of so-called cabuya. On top of this, a $5 \mathrm{~cm}$ bed of mud is applied, in which are set the tiles in order to complete the roofing (Muñoz, 1990).

01. Foundations of interlocking stones

02. Adobe walls

03. Wooden roof structure

04. Wooden mezzanine

05. Corbel

06. Oculus

07. Roof tile

08. Bell tower
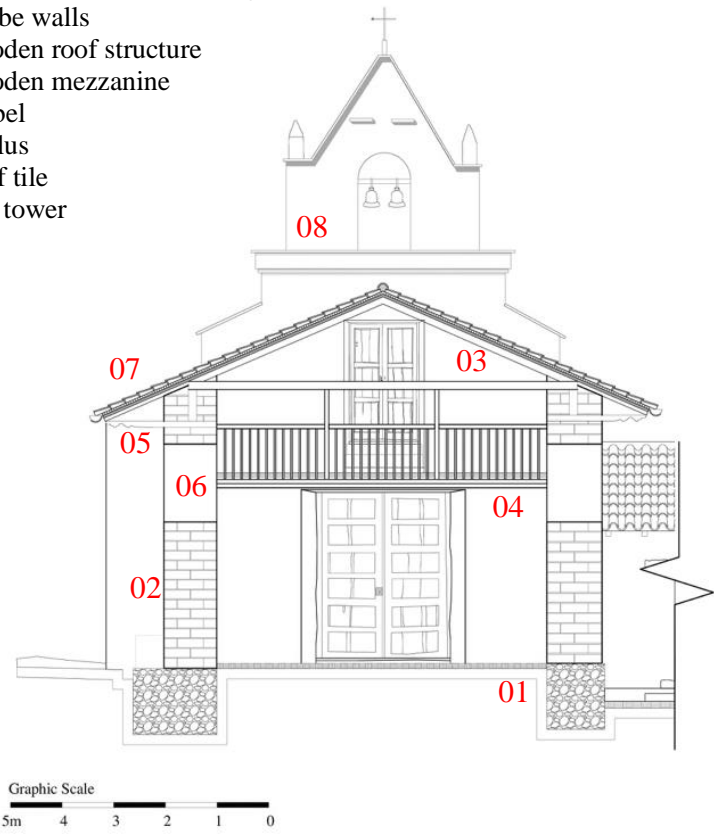

Figure 3. Construction system of the chapel of Susudel, section A-A'. Source: authors.

\subsection{Diagnosis}

Through an on-site survey to investigate the materials, the construction techniques and the damages that affect the stability and the value of the building, several elements were found that are vulnerable and which were in need of immediate interventions. Four types of damages appeared most frequently in the chapel: a) dirt on several elements caused by dust, b) stains on walls and floors caused by water, inappropriate cleaning methods and organic material, c) deterioration of stairs, doors and windows caused by insects, such as beetles and termites, d) cracks in plasters. Other types of damages encountered less frequently are discolorations, erosion, detachments, holes, displacements, paint deposits, fungi and broken edges. Although currently these damages are not very significant, a lack of control

2 Oculi - opening in a wall, with circular, elliptical or mixed shape. (Mesa, 1978) 
could lead to more severe damages in the future. The murals show minor damages, such as small cracks, stains, dirt from insects, deterioration due to bad habits, such as the use of adhesive tape on the murals (Barsallo, 2019). The damage investigation detected several elements that needed urgent interventions, which are included in the recommendations.

Several threats that put the chapel at risk were identified during the diagnosis phase. These threats were determined based on the classification as proposed by Guglielmo de Angelis (Cardoso, 2012), according to which the risk factors are divided into:

a) Intrinsic factors: these are related to the location of the heritage item. The weather (wind, rain, sun) is a risk factor that can cause damages such as stains, fungi, erosion and discoloration. Other risk factors are the use of low quality materials and poorly designed constructive systems, which can be seen in a damaged structure, cracks in the upper part of the high choir and in the junction between the roof and the wall of the façade.

b) Extrinsic factors: threats such as earthquakes, fires, winds, lightning, etc. can cause damages in elements and values of the building. They can lead to among others, cracks, detachments and erosion. Human actions can also cause damages, for example through vibrations caused during the execution of public works, vandalism, such as dirt and graffiti's, and poorly executed maintenance interventions. Together with the diagnosis, these threats are the main ingredients for the conservation plan. Figure 4 shows the threats to which the chapel is exposed.

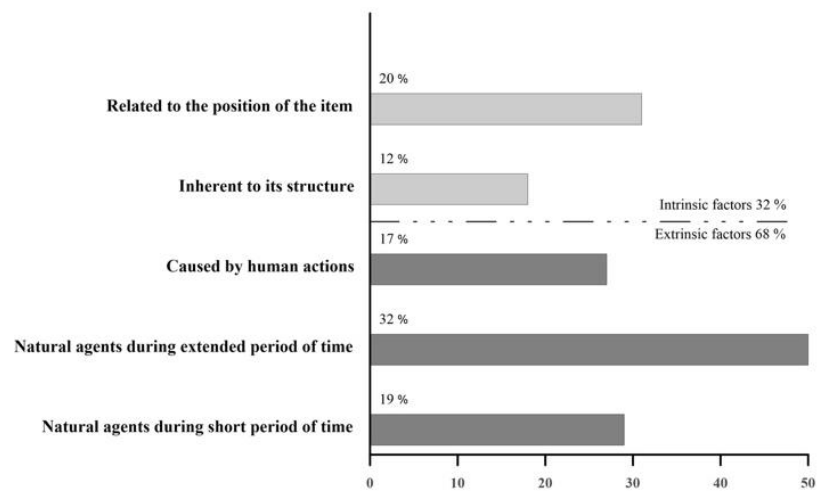

Figure 4. Threats to which the chapel of Susudel is exposed. Source: authors

\subsection{Therapy}

The objectives of the present investigation do not include a restoration proposal, which could be carried out during the therapy phase, but it does include a study of the interventions realized in the past, in order to define the preventive conservation plan. The Chapel was built in the eighteenth century and three interventions were found to have taken place:

a) An inscription in the high altar indicates that the Chapel was rebuild and consecrated in the year 1880. "The chapel was rebuilding... by Mr. José Miguel Valdivieso y Rada, and consecrated today May 17 of 1880, by the Reverend Brother Manuel Valdés, authorized by Monsignor Remigio Estevez de Toral". b) In the 1970's the architect Patricio Muñoz Vega and his technical team realized interventions in the Chapel of Susudel, which was in a serious state of deterioration (Cardoso, 2012).

c) During the Emergency Decree of the year 2008 curative actions and emergency interventions of walls and roofs were carried out in the chapel.

With the knowledge of these interventions, periodic monitoring should be carried out, which is based on the state of conservation identified in the present investigation, which also serves as support for the conservation strategies.

\subsection{Control, preventive conservation strategies for the Chapel of Susudel}

Once the tangible and intangible values of the chapel of Susudel are identified, it is fundamental to maintain and protect this heritage building.

As part of the control phase, several strategies and recommendations focused on the necessity to conserve the chapel are proposed:

- Intervention of the front wall. This should be coordinated by a heritage conservation expert with the help of a construction worker with knowledge of adobe construction techniques.

- Carry out a thorough cleaning of several elements of the chapel, such as floors, windows, doors as well as the furniture and ornaments, establishing a simple daily routine.

- Remove weed and other plants that naturally grow on the floor.

- Carry out a fumigation of the wooden elements to get rid of beetles and termites.

- Clean the stains of the murals. A professional restorer of paintings should coordinate this.

- Cleaning of the gutters before the rainy season begins.

The before mentioned recommendations should be carried out as soon as possible. If this is not possible, a three monthly monitoring of the state of conservation should be implemented.

It is important to mention that, next to the immediate required interventions, a cyclical maintenance process is paramount.

The success of the maintenance actions will depend on the appropriation of the chapel by the neighbors, even more so in places such as Susudel with limited economic and personnel resources. Another important factor is the level of training of the workers responsible for the maintenance.

The strategies of the conservation plan depend on the cyclical process that is going to be carried out in the chapel to guarantee the cultural, historical and architectural values.

It is necessary to identify the people in charge of bringing in practice the strategies, so that each one, with his/her perspective and understanding of the values of the chapel can act in a correct manner. Various stakeholders are identified: a) the caretaker of the chapel, b) the technician of the municipality of Oña, c) cleaning workers, d) restoration expert (Table 1). 


\begin{tabular}{|c|c|c|c|c|}
\hline $\begin{array}{c}\text { Type of } \\
\text { Stakeholder }\end{array}$ & Competence & Maintenance Actions & Frequency & Tool \\
\hline & $\begin{array}{l}\text { Manage the actions that are to be } \\
\text { carried out in the chapel }\end{array}$ & $\begin{array}{l}\text { Realize the interaction with the caretakers and the } \\
\text { municipality to carry out the maintenance actions }\end{array}$ & Yearly & $\begin{array}{l}\text { Verbal or written } \\
\text { coordination }\end{array}$ \\
\hline \multirow[t]{2}{*}{$\begin{array}{l}\text { Caretaker of the } \\
\text { chapel }\end{array}$} & & $\begin{array}{l}\text { Monitoring of potential dangers, condition of the roofs, } \\
\text { windows, gutters, cracks in the walls, humidity, etc. }\end{array}$ & Quarterly & $\begin{array}{l}\text { Damage identification } \\
\text { card }\end{array}$ \\
\hline & Foster the good care of the chapel & & & \\
\hline
\end{tabular}

$\begin{array}{lll}\text { Take care of items within the chapel Observation } & \text { Weekly }\end{array}$

\begin{tabular}{|c|c|c|c|c|}
\hline \multirow{2}{*}{$\begin{array}{l}\text { Technician of } \\
\text { the municipality } \\
\text { of Oña }\end{array}$} & $\begin{array}{l}\text { Realize inspections, monitor elements } \\
\text { through the reference system (values - } \\
\text { damages), run the database to identify } \\
\text { damages and causes. Plan actions } \\
\text { based on the needs resulting from the } \\
\text { inspections. }\end{array}$ & $\begin{array}{l}\text { Realize inspections - apply the monitoring card and } \\
\text { generate reports. Plan maintenance actions to protect } \\
\text { the chapel. }\end{array}$ & \multirow[t]{2}{*}{ Half-yearly } & \multirow[t]{2}{*}{$\begin{array}{c}\text { Monitoring card / } \\
\text { technical report }\end{array}$} \\
\hline & $\begin{array}{l}\text { Realize inspections in case of disaster } \\
\text { with the cooperation of a safety } \\
\text { professional and the fire department }\end{array}$ & Be wary of natural disasters & & \\
\hline \multirow{7}{*}{ Cleaning Staff } & \multirow{7}{*}{ Keep the chapel clean and tidy } & Cleaning of the interior & Daily (according to use) & \multirow{7}{*}{ Cleaning materials } \\
\hline & & Cleaning of gutters & $\begin{array}{c}\text { Before the rainy season } \\
\text { (January - May) }\end{array}$ & \\
\hline & & Cleaning of roofs & Yearly & \\
\hline & & Cleaning of floors & Weekly & \\
\hline & & Taking care of plants & Quarterly & \\
\hline & & Cleaning of woodwork & Weekly & \\
\hline & & Cleaning and taking care of furniture and other items & Weekly & \\
\hline \multirow{4}{*}{$\begin{array}{l}\text { Specialist - } \\
\text { Expert }\end{array}$} & \multirow{4}{*}{$\begin{array}{l}\text { Coordination with the municipal } \\
\text { technician (yearly reports). Realize the } \\
\text { preventive maintenance actions. Verify } \\
\text { the condition of the walls, plumbing, } \\
\text { electrical system }\end{array}$} & Take care of the murals & \multirow{2}{*}{ Every two years } & \multirow{4}{*}{ Plan of actions } \\
\hline & & Painting of interior walls and facades & & \\
\hline & & Repair of plasters & When needed & \\
\hline & & General repairs & When needed & \\
\hline
\end{tabular}

Table 1. Identification of stakeholders and the activities to be carried out for the monitoring of the chapel. Source: Barsallo, 2019

\section{CONCLUSIONS}

The chapel of Susudel is one of the best-preserved examples of religious vernacular architecture in a rural setting in the province of Azuay. This investigation includes a thorough analysis of the traditional materials and construction techniques typical of the colonial era. It's over $1 \mathrm{~m}$ wide adobe walls, oculi, niches, bell tower and the wooden roof structure are some of the

significant elements of this heritage building. The chapel has had several maintenance interventions throughout its history. In order for this maintenance process to continues, it is in need of a preventive conservation plan, since it currently presents damages that need to be repaired to avoid its deterioration and future destruction.

Various chemical, physical and mechanical processes have caused damages in the chapel of Susudel. It is clear that the processes of deterioration are the result of actions by atmospheric agents. It is worth emphasizing that no natural or synthetic material can withstand a constant lack of maintenance.
With regard to the damage analysis, it was found that none of the damages causes an immediate threat to the stability of the chapel. However, many damages of lesser threat were discovered, which without proper maintenance could eventually negatively affect the chapel. Furthermore, one should keep in mind that damages affect the heritage values of the chapel.

It is therefore that systematic routine maintenance of the chapel should be implemented, taking into account that control is a cyclical process that requires an interdisciplinary and permanent focus with the involvement of restoration experts, technicians and the engagement of the owners.

The importance of preventive heritage maintenance goes hand in hand with the rescue of the intangible values that provide its identity to a place. The chapel of Susudel promotes the social cohesion, in addition to being a local landmark.

Having a preventive conservation plan ensures the conservation of the tangible and intangible values of the chapel. It is necessary to count on the active involvement of all the stakeholders from the beginning to the end of the interventions to guarantee the survival of the chapel. 


\section{REFERENCES}

Achig-Balarezo, M. C., Jara, D., Cardoso, F., Van Balen, K., 2014. Hacia un Plan Piloto de Conservación Preventiva basado en la Campaña de Mantenimiento de San Roque. Estoa. Revista de la Facultad de Arquitectura y Urbanismo de la Universidad de Cuenca, 0(5), 37-50.

Achig-Balarezo, M. C., Barsallo Chávez, M. G., Briones, J. C., Cardoso Martínez, F., 2016. Heritage building's condition at Maintenance Campaign in San Roque, Cuenca - Ecuador. SAHC 2016: 10th International Conference on Structural Analysis of Historical Constructions. Lovaina, Bélgica. Published in Structural Analysis of Historical Constructions. Anamnesis, diagnosis, therapy, controls, Van Balen, Els Verstrynge (Eds.), p. 151-157.

Achig-Balarezo, M. C., Barsallo, G., 2018. El atlas de daños y su aplicación como herramienta de gestión para el patrimonio de la ciudad de Cuenca - Ecuador. IV Encuentro PRECOM ${ }^{3} O S$ : Preventive Conservation Maintenance and Monitoring of Monuments and Sites. Patrimonio y desarrollo frente a las trasformaciones. 2nd, 3rd October, Cuenca, Ecuador. Proceedings published in Arte y Sociedad. Revista de Investigación, EUMEDNET (No.14) enero, 2018. (https://dialnet.unirioja.es/servlet/articulo?codigo=6266255)

Astudillo, S., 2011. Los desafíos del Plan de Conservación Preventiva, Monitoreo y Mantenimiento, (PCPM2) en Cuenca. II Encuentro PRECOM3OS Seminario. Taller de Tecnologías y restauración de obras en tierra. Universidad de Cuenca, FAUC, Proyecto vlirCPM.Cuenca, Ecuador.

Avrami, E., Mason, R. n/d. Los valores en el Proceso de planificación, p. 3

Barsallo Chávez, M. G., 2019. Plan de conservación preventiva, estudio de caso: la capilla de Susudel. Master's tesis retrieved from (http://dspace.ucuenca.edu.ec/handle/123456789/32099)

Caldas, V., Sigcha, X., 2017. Breve análisis cronológico de la introducción de materiales relevantes, dentro de las edificaciones del Centro Histórico de Cuenca entre los años 1880 y 1980. Degree thesis, Universidad de Cuenca.

Cardoso, F., 2012. Manuales de Conservación Preventiva aplicada para sitios arqueológicos $Y$ tramos arquitectónicos Coyoctor, Cojitambo, Chobshi y Todos Santos, Quingeo, Jima. Instituto Nacional de Patrimonio Cultural, (INPC), Cuenca,Ecuador.

Cardoso, F., 2012. Proyecto de rehabilitación plaza de Susudel, parroquia de Susudel, provincia del Azuay. Ministerio Coordinador de Patrimonio.

Cardoso, F., Achig, M. C., Vázquez, L., Barsallo, G., 2016. La conservación preventiva en tierra en el sur del Ecuador. XII Congreso Mundial de arquitectura de tierra. Lyon Francia 2016.

Cardoso, F., Achig-Balarezo, M., Barsallo, G., 2018. Preventive conservation tools in southern Ecuador. Journal of Cultural Heritage Management and Sustainable Development, Vol. 8 No. 2, pp. 207-220. (https://doi.org/10.1108/JCHMSD-06-2017-0033)

Della Torre, S., 2013. Planned Conservation and Local Development Processes: the Key Role of Intellectual Capital. Reflections on Preventive Conservation. Maintenance and Monitoring of Monuments and Sites, PRECOM 3 OS UNESCO Chair, Van Balen, Vandesande (Eds.). ACCO. Leuven, Belgium. p. $123-127$
García, G., Amaya, J., Ordoñez, S., 2016. Desafíos de los procesos de producción y construcción en adobe en América Latina, retos y oportunidades. 16th SIACOT 2016, p. 36-47.

Gandreau, T., Delboy, D., Joffroy, L., 2012. World Heritage Earthen Architecture Programme.

ICOMOS, 2003. Principles for the analysis, conservation and structural restoration of architectural heritage, Art. 1.6. Downloaded (http://www.icomos.org/charters/structures_e.pdf , last consulted 12/01/2020)

ICOM-CC, 2008. Terminology to characterize the conservation of tangible cultural heritage. Downloaded (http://www.icomcc.org/242/about-icom-cc/what-is-

conservation/\#.XrTACc2Qxdh last consulted: 04/01/2020)

ICOMOS, 2014. Recommendations for the Analysis, Conservation and Structural Restoration of Architectural Heritage. Iscarsah International Scientific Committees on the Analysis and Restoration of Structures of Architectural Heritage Guidelines. Downloaded (https://iscarsah.org/documents last consulted 02/01/2020)

Lloret, G., Montesinos, D., Brazzero, M., Brazzero, D., 2008. Pre proyecto de desarrollo comunitario para la parroquia de Susudel a través de su legado cultural. Not published.

Martínez Borrero, J., 1997. De lo Divino y lo Profano, Arte Cuencano de los Siglos XVIII y XIX. Ediciones del Banco Central del Ecuador, Cuenca.

Muñoz, M., 1990. The rural heritage of Ecuador. The hacienda of Susudel. Thesis for the second year to obtain the master degree. Centre for the conservation of historic towns and buildings. Katholieke Universiteit Leuven.

Muñoz, P., 2015. Arquitectura popular en Azuay y Cañar $1977-$ 1978. Cuadernos de trabajo de Patricio Muñoz Vega y compilación gráfica. CIDAP, Universidad de Cuenca. Cuenca, Ecuador.

Mesa, J., 1978. Glosario mínimo de términos de arquitectura Virreynal en el área Andina. Centro de investigación y restauración de bienes monumentales, Instituto Nacional de Cultura. Cusco, Perú.

Paniagua, J., 1993. La Iglesia de Susudel Azuay (Ecuador). Anales del Museo de América, p. 143-157.

Piedra, C., 2008. Soluciones a daños en edificaciones patrimoniales construidas con tecnologías tradicionales. Universidad de Cuenca.

Santana, M., 2013. Heritage recording, documentation and information systems in preventive maintenance. Reflections on Preventive Conservation. Maintenance and Monitoring of Monuments and Sites. PRECOM3OS UNESCO Chair, Van Balen, Vandesande (Eds.). ACCO. Leuven-Belgium. p. 10-17

UNESCO, 1994. Nara Document on Authenticity. ICCROMICOMOS. Downloaded nara94.htm last consulted 12/01/2020).

Van Balen, K., 2008. The Nara Grid: An Evaluation Scheme Based on the Nara Document on Authenticity. APT Bulletin: The Journal of Preservation Technology, vol. 39, $\mathrm{n}^{\circ} .2 / 3$. 